\title{
Incidencia y distribución altitudinal de 13 virus en cultivos de Solanum tuberosum (Solanaceae) en Costa Rica
}

\author{
Viviana Vásquez ${ }^{1 \dagger}$, Mauricio Montero-Astúa \& Carmen Rivera ${ }^{1,2}$ \\ 1 Centro de Investigación en Biología Celular y Molecular, Universidad de Costa Rica, 2060 San José, Costa Rica. Fax: \\ (506) 2073190. \\ 2 Facultad de Microbiología, Universidad de Costa Rica, 2060 San José, Costa Rica; crivera@racsa.co.cr \\ $\dagger \quad$ Fallecida 14-XII-2005.
}

Recibido 14-VI-2004. C Corregido 20-X-2005. Aceptado 07-III-2006.

\begin{abstract}
Incidence and altitudinal distribution of 13 virus cultures in Solanum tuberosum (Solanaceae) from Costa Rica. A survey was conducted in 30 fields located at three different altitudes in Cartago, Costa Rica's main potato producing area. Twenty plants were sampled per farm, for a total of 600 samples with 200 samples per altitude. ELISA was used with commercial reagents to independently test for PVX, PVY, PVM, PVA, PVS, PLRV, PMTV, PAMV, PVV, PVT, APLV, APMoV and TRSV. The presence of the following viruses was determined: PVX (77 \%), PAMV (62 \%), PLRV (42 \%), TRSV (42\%), PVT (39\%), PVV (37 \%), PMTV (31\%), PVY (30\%), PVS (19\%), PVM (13\%), PVA (8\%), and APMoV (8\%). APLV was not detected in any sample. This is the first report in Costa Rica of the presence of the viruses PMTV, PAMV, PVV, PVT and APMoV. A high viral incidence in the tuber seed production area as well as a high rate of mixed infections is reported. Rev. Biol. Trop. 54 (4): 1135-1141. Epub 2006 Dec. 29.
\end{abstract}

Key words: potato viruses, diagnosis, DAS-ELISA, TAS-ELISA, epidemiology, seed-potato.

La producción comercial de papa en Costa Rica, se realiza principalmente mediante propagación vegetativa, tomando tubérculos aparentemente sanos, de una cosecha previa de papa comercial y utilizándolos como semilla para la siguiente siembra. A través de este tipo de material de siembra son transmitidas muchas enfermedades, principalmente virales, de una generación a otra. Además el uso continuo de materiales infectados por virus incrementa la incidencia de ellos en el campo y degenera el cultivo (Salazar 1995).

En Costa Rica, se informó la incidencia de: "Potato virus $X$ " (PVX), "Potato virus $Y$ ” (PVY), "Potato virus S" (PVS), "Potato virus $M$ " (PVM), "Potato virus A" (PVA) y del "Potato leafroll virus" (PLRV) (Espinoza y Gámez 1977, Ramírez-Martínez y Gámez 1980, Hord y Rivera 1998). Estos virus junto con el virus del ápice fasciculado de la papa o
"Potato mop-top virus" (PMTV), son conocidos en el ámbito mundial por su efecto en el rendimiento de este cultivo. También se han informado para Costa Rica el "Tobacco mosaic virus" (TMV) y el "Tobacco ringspot virus" (TRSV) (Solís 1989).

En Centroamérica y Sudamérica, se han registrado además, otros virus tales como: el "Potato virus V" (PVV), el "Potato virus $T$ ” (PVT), el "Andean potato mottle virus" (APMoV), el "Potato aucuba mosaic virus" (PAMV) y "Andean latent mosaic virus" (APLV) (Brunt et al. 1996).

Como la mayoría de los virus de la papa son fácilmente transmitidos por los tubérculos y varios de ellos pueden afectar la producción o la calidad del tubérculo, es necesario identificar cuáles virus están en el país y cuál es su distribución. Esto contribuirá a fortalecer el programa nacional de certificación de semilla, 
para lograr reducir los porcentajes de infección viral y obtener un cultivo de papa de mejor calidad y mayor rendimiento.

Los principales objetivos de este trabajo fueron determinar la presencia, incidencia y distribución de los virus TRSV, PMTV, PVV, PVT, APMoV, APLV y PAMV en tres zonas altitudinales, en la región de mayor producción de papa; además comparar la prevalencia actual de los virus PVX, PVY, PLRV, PVA, PVS, PVM con la encontrada durante 1998.

\section{MATERIALES Y MÉTODOS}

Recolección de muestras: Se realizó un muestreo en la zona norte de Cartago, de enero a julio del año 2001, en tres diferentes altitudes: zona alta, a más de $2500 \mathrm{msnm}$, dedicadas principalmente a la producción de semilla; zona media, de 1800 a 2500 msnm, y zona baja, que abarca aquellos cultivos que se encuentren a menos de $1800 \mathrm{msnm}$. En las altitudes media y baja se siembra papa principalmente para consumo fresco e industrial. Se utilizaron como criterios para definir los lugares de muestreo, la ubicación geográfica de la finca, el estado fisiológico del cultivo (plantas en flor) y la disponibilidad de los agricultores para colaborar en el proyecto. En cada altitud se seleccionaron diez parcelas, cada una de 500 a $750 \mathrm{~m}^{2}$. Para el muestreo se dividió cada parcela en cuatro subparcelas semejantes. En cada subparcela se seleccionaron aleatoriamente cinco plantas en floración, de las cuales se recolectaron entre diez y 12 hojas distribuidas en la parte media y la parte superior de la planta. En total se muestrearon 20 plantas por parcela. Se muestrearon un total 30 parcelas y 200 plantas por altitud.

Procesamiento y análisis de las muestras: Las hojas recolectadas se empacaron en bolsas individuales y se trasportaron al laboratorio. Luego se congelaron a $-70{ }^{\circ} \mathrm{C}$ por un período máximo de tres semanas. Las muestras se maceraron a una dilución de $1: 3 \mathrm{p} / \mathrm{v}$ en una solución amortiguador de fosfato de potasio $0.01 \mathrm{M}, \mathrm{pH} 7.4$, que contenía cloruro de sodio al $0.85 \%$ (PBS), sulfito de sodio al $0.13 \%$, polivinilpirrolidona (PVP) al $2 \%$, albúmina sérica bovina (BSA) al $0.2 \%$, y Tween-20 al $2 \%$, en un macerador de rodillo. Los extractos de las muestras de las 20 plantas por parcela, se analizaron individualmente para la presencia de PVA, PVM, PVS, PLRV, PVX, PVY, APLV, PAMV, PVT, PVV y TRSV, utilizando el método DAS-ELISA ("double antibody sandwich enzyme-linked immunosorbent assay”), con anticuerpos de recubrimiento, anticuerpos conjugados con fosfatasa alcalina, controles positivos y negativos, y los protocolos de la casa comercial AGDIA (Elkhart, Indiana, USA). Las muestras se analizaron además para PMTV y APMoV mediante TAS-ELISA ("triple antibody sandwich enzyme-linked immunosorbent assay") con reactivos y protocolos de la casa comercial ADGEN (Scotland, UK). Las lecturas de absorbancia a $460 \mathrm{~nm}$ se tomaron en un lector de placas de ELISA Dynex MRX, 120 min después de añadir el sustrato. Como sustrato se utilizó p-nitrofenil fosfato a una concentración de $1 \mathrm{mg} / \mathrm{ml}$, en una solución amortiguadora de $\mathrm{pH}$ 9.8, que contenía $9.7 \%$ de dietanolamina y $0.01 \%$ de cloruro de magnesio hexahidratado. Se consideraron como plantas infectadas o positivas, todas aquellas muestras con un valor de absorbancia mayor o igual a la media de la absorbancia de las muestras sanas control $(\mathrm{n}=2)$, más tres veces la desviación estándar. Todos los valores menores a este criterio se consideraron plantas no infectadas o negativas.

\section{RESULTADOS}

De los trece virus analizados en las plantaciones de papa de la zona de Cartago, se detectaron 12 de ellos. El PVX se encontró en el $77 \%$ de las muestras analizadas, seguido del PAMV con un $62 \%$, TRSV con un $42 \%$, PLRV $41 \%$, PVT $39 \%$, PVV $37 \%$, PMTV $31 \%$, PVY $30 \%$, PVS $19 \%$, PVM $13 \%$, APMoV 8 \% y PVA en el $6 \%$. No se encontró APLV en ninguna de las muestras analizadas (Fig. 1). 
Del total de las muestras analizadas para el virus PAMV, se detectaron infectadas el $77.5 \%$ en la zona alta, un $44 \%$ en la zona media y el $63 \%$ de la zona baja (Fig. 2). Este virus se detectó en el $90 \%$ de las parcelas de la zona alta, en el $70 \%$ de las parcelas de la zona media y en el $100 \%$ de las parcelas en la zona baja (Fig. 3). En 11 de las 30 parcelas analizadas se encontró en el $100 \%$ de las muestras y en las demás parcelas superó el 50 \%.

El PMTV se encontró en el $25 \%$ de las muestras analizadas en la zona alta, en el $50 \%$ de la zona media y $15 \%$ de la zona baja. En la zona alta se detectó en el $50 \%$ de las parcelas, en el $60 \%$ de la zona media y en el $50 \%$ de la zona baja. La incidencia de plantas infectadas por parcela fue de un $45 \%$ en la zona alta, $17 \%$ en la zona media y un $15 \%$ en la zona baja (Fig. 2, 3).

La cantidad de muestras positivas para PVT alcanzó un $18 \%$ en los cultivos de la zona alta y se encontró en el $30 \%$ de las parcelas. En la zona media se detectó en el $70 \%$ de las parcelas, en más del $50 \%$ de las plantas por parcela. En la zona baja se detectó en más del $40 \%$ de las muestras y en el $90 \%$ de las parcelas (Fig. 2, 3).

El PVV se detectó en el $80 \%$ de las parcelas estudiadas en la zona alta con un promedio de infección del $50 \%$ por parcela. Además, se detectó en el $80 \%$ de las parcelas de la zona media infectando el $40 \%$ de las plantas. En la zona baja fue más escaso, se detectó en el 40 \% de las parcelas con un $20 \%$ de promedio de infección por parcela (Fig. 2, 3).

El virus TRSV se detectó en el $70 \%$ de las parcelas de las zonas media y alta, y en el $50 \%$ en la zona baja. El promedio de infección fue alrededor del $45 \%$ en todas las parcelas (Fig. 2, 3).

El APMoV no se encontró en la zona alta. En la zona baja se encontró en el $30 \%$ de las parcelas con una infección del $15 \%$ por parcela. En la zona media se detectó en el $20 \%$ de las parcelas con una infección inferior al $10 \%$ por parcela (Fig. 2, 3).

Todas las parcelas estuvieron infectadas con al menos dos de los virus analizados. El

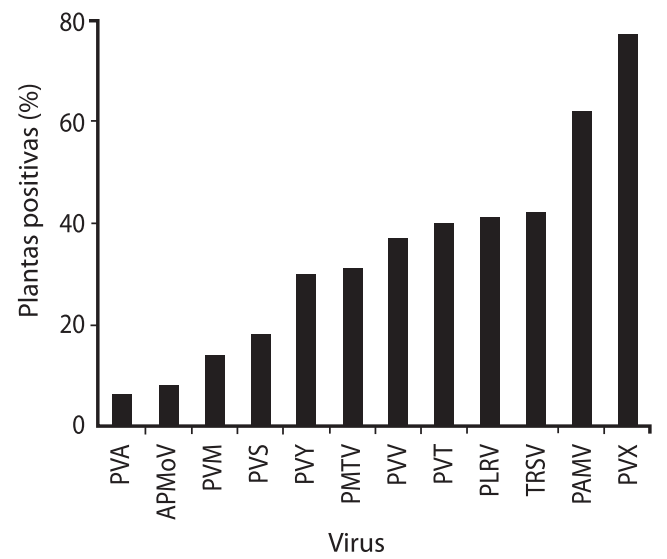

Fig. 1. Porcentaje de plantas infectadas con los doce virus detectados en la provincia de Cartago.

Fig. 1. Percentage of infected plants with the twelve virus detected in the Cartago province.

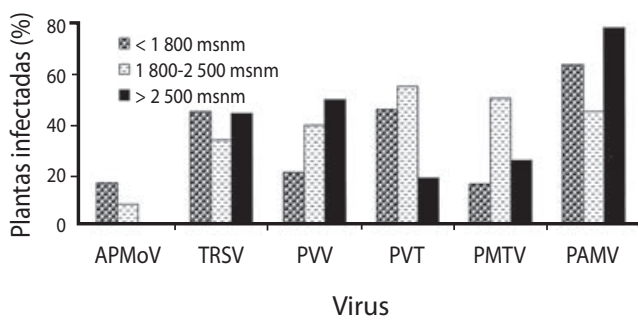

Fig. 2. Porcentaje de plantas infectadas con APMoV, TRSV, PVT, PMTV y PAMV en las tres zonas de altitud evaluadas.

Fig. 2. Percentage of infected plants with APMoV, TRSV, PVT, PMTV and PAMV in the three evaluated altitudinal zone.

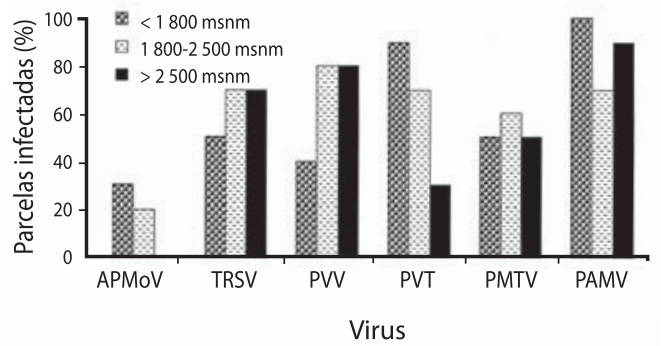

Fig. 3. Porcentaje de parcelas infectadas con APMoV, PVV, PVT, PMTV, PAMV y TRSV en cada zona altitudinal.

Fig. 3. Percentage of infected fields with APMoV, PVV, PVT, PMTV, PAMV and TRSV at each altitudinal zone. 
número de virus encontrados por parcela analizada varió de dos a diez, con un promedio de cinco virus. El $44 \%$ de las parcelas presentaron más de siete virus. Las infecciones mixtas en plantas individuales fueron muy comunes. En promedio se detectaron cuatro virus por planta.

De los seis virus previamente informados para Costa Rica, el PVX se detectó en el $100 \%$ de las fincas analizadas. La infección en la zona baja fue de $85 \%$ por parcela. En la zona alta hubo un promedio de $65 \%$ de infección por parcela. En el $50 \%$ de las fincas analizadas, todas las plantas fueron positivas para este virus (Fig. 4, 5).

El PLRV se detectó en el $80 \%$ de las parcelas de la zona alta y media, y en el $50 \%$ de las parcelas de la zona baja. El porcentaje de infección por parcela, fue similar en todas las zonas con un promedio de $50 \%$. El PVY se encontró en el $70 \%$ de las parcelas de la zona baja y en el $60 \%$ de las de la zona alta y media. La infección promedio por parcela en la zona alta fue de $65 \%$ y en las zonas baja y media fue de $35 \%$ (Fig. 4, 5).

El PVS se detectó principalmente en la zona media, en el $60 \%$ de las parcelas con una infección promedio por parcela de 75 \%. La zona baja tuvo $40 \%$ de parcelas infectadas con un promedio de infección por parcela menor al $10 \%$. El PVM se encuentra en el $40 \%$ de las parcelas de la zona baja y en el $30 \%$ de las parcelas de la zona media y alta, pero el promedio de infección por parcela en la zona alta fue de $18 \%$ en promedio y para la zona baja un $6 \%$ (Fig. 4,5 ).

El PVA se detectó en el $30 \%$ de las parcelas de la zona media con un promedio de infección del $8 \%$. El $20 \%$ de las parcelas de la zona alta presentaron un promedio de infección del 9 \% y las parcelas de la zona baja un $10 \%$ (Fig. 4, 5).

\section{DISCUSIÓN}

Nuestros resultados evidencian la presencia de 12 de los 13 virus analizados en el cultivo de la papa, en la zona norte de Cartago en Costa Rica (Fig. 1). De estos doce virus, PAMV, APMoV, PVV, PVT y PMTV se informan por primera vez para Costa Rica en este estudio, el

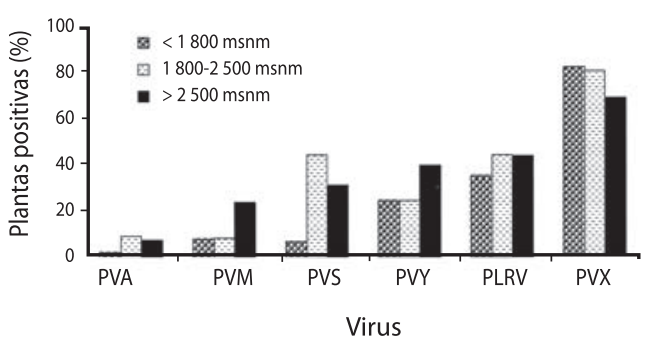

Fig. 4. Porcentaje de plantas infectadas con los virus PVA, PVX, PVY, PLRV, PVM y PVS según la zona altitudinal.

Fig. 4. Percentage of infected plants with PVA, PVX, PVY, PLRV, PVM and PVS virus at each altitudinal zone.

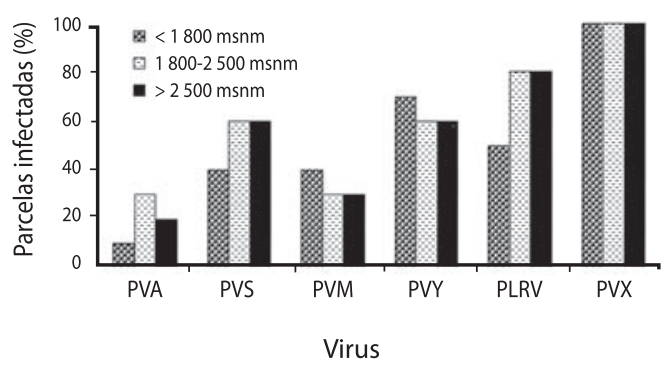

Fig. 5. Porcentaje de parcelas infectadas con PVX, PLRV, PVY, PVM, PVS y PVA según la zona altitudinal.

Fig. 5. Percentage of infected fields with PVX, PLRV, PVY, PVM, PVS and PVA at each altitudinal zone.

resto de los virus se informaron previamente (Espinoza y Gámez 1977, Ramírez-Martínez 1980, Solís 1989, Hord y Rivera 1998).

Estos resultados también evidencian la amplia distribución que estos virus tienen en las tres zonas altitudinales estudiadas en Cartago (Fig. 2, 4). Los doce virus encontrados en esta zona fueron detectados en las tres altitudes, con excepción del APMoV, el cual no se detectó en ninguna de las parcelas de la zona alta (Fig. 2, 3). En general, en todas las parcelas estudiadas se detectaron por lo menos dos virus y en la mayoría de cinco a siete.

Entre los nuevos virus estudiados, el PAMV fue el más frecuente (Fig. 2). El PAMV además de encontrarse en la mayoría de las parcelas de las tres altitudes, presentó una alta incidencia por parcela, incidencia que fue del $100 \%$ en 11 parcelas y más del $50 \%$ en el resto de ellas. 
El PAMV presenta una amplia distribución en Centro y Sudamérica (Brunt et al. 1996), por lo que no es extraño que se encuentre en Costa Rica con tan alta incidencia. Este virus se transmite por contacto entre plantas, tubérculosemilla y en forma mecánica mediante herramientas y maquinaria (Salazar 1995), por lo que su diseminación en el campo puede ocurrir fácilmente si no se realiza un manejo adecuado del cultivo. Según Baulcombe et al. (1993) el PAMV también es transmitido por áfidos en forma asistida por PVY o PVA, situación que podría explicar por qué en la mayoría de las parcelas donde se detectó el PVY también se encontró PAMV.

El PVV presentó una incidencia del $36 \%$ (Fig. 1). Este virus se transmite en forma mecánica y mediante áfidos de manera no persistente, por semilla sexual y polen (Brunt et al. 1996). Está relacionado serológicamente con algunas razas de PVY (Spetz et al. 2003). Posiblemente, debido a esto en la mayoría de las parcelas donde estuvo presente el PVT, también se encontró PVV.

El PMTV es transmitido principalmente por Spongospora subterranea (Savenkov et al. 1999). Este plasmodioforomicete es muy difícil de combatir, sus esporas de resistencia son capaces de permanecer en el campo por años, portar el virus y transmitirlo a los tubérculos en el campo (Arly Sokmen et al. 1998). Su dispersión se ve favorecida en terrenos húmedos y a bajas temperaturas. La presencia de $S$. subterranea se informó en varias parcelas ubicadas en las zonas media y alta (Montero-Astúa et al. 2002), zonas con una precipitación y humedad mayor que las presentes en la zona baja. Este hallazgo se puede relacionar con la mayor incidencia del PMTV en las zonas media y alta en comparación con la zona baja (Fig. 2).

El APMoV presentó una baja incidencia en este estudio (Fig. 1), situación similar a la que se presenta en otros países y a diferencia de la zona andina donde es muy abundante (Brunt et al. 1996, Stevenson 2001) y donde se informó por primera vez. Se transmite por coleópteros, por contacto entre plantas y en forma mecánica. La baja incidencia que se encontró en Costa Rica podría deberse entre otros factores, a que el APMoV haya sido de muy reciente introducción al país y que aún no se haya diseminado por toda la región papera, o que las variedades sembradas posean cierta resistencia a este virus.

Al comparar los resultados obtenidos por Hord y Rivera (1998), con la información de este estudio, se comprobó que el virus PVX continúa siendo el más abundante. Además, se observó un aumento en la incidencia del PVS y se notó una disminución en PVA, PLRV, PVY y PVM. La disminución de estos virus podría deberse a los esfuerzos de los últimos años, por enseñar al agricultor sobre la importancia de utilizar una semilla libre de virus.

Las infecciones mixtas fueron muy frecuentes, en promedio cuatro virus por planta (datos no mostrados). Este tipo de infecciones pueden provocar un efecto sinérgico y agravar los síntomas en la planta, y como consecuencia una mayor disminución en el rendimiento. Una de las hipótesis para entender este tipo de infección, es la posibilidad de que los áfidos estén infectados con varios virus, y en el momento de realizar las pruebas de alimentación o alimentarse efectivamente, los transmitan a la vez. Otra de las posibilidades es la encapsidación heteróloga, que consiste en que dos virus diferentes se encapsidan dentro de la misma cubierta proteica y son transmitidos simultáneamente por áfidos. Esta condición es transitoria, y ocurre en la naturaleza entre virus compatibles (Nelson y Wheeler 1981). La compatibilidad de los virus no está bien definida, aunque se sabe que la estructura del virus es determinante, pues es muy poco probable encontrar encapsidación heteróloga entre un virus esférico y uno alargado (Elnagar y Murant 1976). Esto coincide con que la mayoría de las infecciones mixtas detectadas en este estudio ocurrieron entre virus alargados como PAMV, PVX, PVY, PVV y PVT.

Es interesante destacar que en la zona dedicada a la producción de semilla, la incidencia de virus transmitidos por áfidos, tales como PVM, PVS, PVY, PRLV y PVV, así como, la del potexvirus PAMV, que puede ser transmitido por áfidos a partir de plantas con infección 
mixta de PVA o PVY, fue del $20 \%$ hasta un $77.5 \%$. Esto se observó a pesar de que varios estudios indican que las poblaciones de áfidos vectores disminuyen a altitudes mayores a 2500 msnm (Chacón 1980, Meneses y Amador 1990). Por esta razón, se acostumbra ubicar las parcelas para producción de semilla a una altitud mayor a $2500 \mathrm{msnm}$, región donde se considera que el riesgo de infección es mínimo. Sin embargo, la presencia de áfidos vectores en la zona de producción de semilla, aunque en poblaciones bajas, parece ser suficiente para la transmisión de virus, con un aumento paulatino en la incidencia a través de varias siembras sucesivas (Hord y Rivera 1998). El hecho de que estos virus se detecten en la zona alta con una incidencia alta, puede deberse también, a la siembra de tubérculos infectados en los campos, lo que facilita la diseminación por áfidos.

Debido a la alta incidencia de virus informada en este estudio, es indispensable crearle conciencia al agricultor de iniciar su siembra con semilla libre de virus y renovar la semilla periódicamente, para lograr reducir la dispersión de las enfermedades virales en el campo. Asimismo, es necesario fortalecer el Programa Nacional de Certificación de Semilla, para facilitar a los agricultores el acceso a semilla libre de virus.

Este estudio demostró la alta incidencia de virus en la zona norte de Cartago y no se descarta la posible presencia de otros virus no estudiados hasta ahora.

\section{AGRADECIMIENTOS}

Se agradece el financiamiento de este proyecto al convenio Costa Rica-Países Bajos (Fundecooperación), al Programa de Caracterización y Diagnóstico de Virus y Viroides en Cultivos de Importancia Económica y Alimentaria del Centro de Investigación en Biología Celular y Molecular (PCDV-CIBCM) y a la Universidad de Costa Rica (UCR).

\section{RESUMEN}

En Cartago, la zona productora de papa más importante de Costa Rica, se realizó un muestreo en 30 fincas ubicadas a tres altitudes. Se recolectaron 20 plantas por finca y 200 muestras por altitud. Todas las muestras se analizaron independientemente mediante ELISA, para PVX, PVY, PVM, PVA, PVS, PLRV, PMTV, PAMV, PVV, PVT, APLV, APMoV y TRSV, utilizando reactivos comerciales. Se identificó la presencia de PVX (77\%), PAMV (62 \%), PLRV (42\%), TRSV (42\%), PVT (39\%), PVV (37\%), PMTV (31\%), PVY (30\%), PVS (19\%), PVM (13\%), PVA (8\%), y APMoV (8\%). No se detectó APLV en ninguna de las muestras analizadas. Se informan por primera vez la presencia en Costa Rica de los virus PMTV, PAMV, PVV, PVT y APMoV. Se informa la alta incidencia viral en la zona dedicada a la producción de tubérculos como semilla y la alta tasa de infecciones mixtas.

Palabras clave: virus de la papa, diagnosis, DAS-ELISA, TAS-ELISA, epidemiología, semilla de papa.

\section{REFERENCIAS}

Arly Sokmen, M., H. Barker \& L. Torrance. 1998. Factors affecting the detection of Potato mop-top virus in potato tubers and improvement of test procedures for more reliable assays. Ann. Appl. Biol. 133: 55-63.

Baulcombe, D.C., J. Lloyd, I.N. Manousopolus, I.M. Roberts \& B.D. Harrison. 1993. Signal for Potyvirusdepend aphid transmission of Potato aucuba mosaic virus and the effect of its transfer to potato virus $\mathrm{X}$. J. Gen. Virol. 74: 1245-1253.

Brunt, A., K. Crabtree, M. Dallwitz, A. Gibbs \& L. Watson. 1996. Viruses of plants; descriptions and list from the Video Database. CAB International. Cambridge University, Cambridge, Reino Unido. p. 150-151

Chacón, M.C. 1980. Evaluación de la población de áfidos alados en cultivos de papa para semilla en la zona norte de Cartago. Tesis de Grado, Universidad de Costa Rica, San José, Costa Rica. 185 p.

Elnagar, S. \& A.F. Murant. 1976. The role of the helper virus, anthriscus yellows, in the transmission of parsnip yellow fleck virus by the aphid Cavariella aegopodii. Ann. Appl. Biol. 84: 169-181.

Espinoza, A.M. \& R. Gámez. 1977. Incidencia del virus del enrollamiento de las hojas de la papa en lotes comerciales de semilla en Costa Rica. Fitopatología 12: 97-98. 
Hord, M. \& C. Rivera. 1998. Prevalencia y distribución geográfica de los virus PVX, PVY, PVA, PVM, PVS, y PLRV en el cultivo de la papa en la zona norte de Cartago, Costa Rica. Agron. Costarricense 22: 137-143.

Meneses, R. \& R. Amador. 1990. Monitoreo de áfidos y su relación con el programa de semilla de papa en Costa Rica. Manejo Integr. Plagas 15: 45-52.

Montero-Astúa, M., V. Vásquez \& C. Rivera. 2002. Ocurrence of potato Powdery Scab, caused by Spongospora subterranea f.sp. subterranea, in Costa Rica. Plant Dis. 86: 1161.

Nelson, M.R. \& R.E. Wheeler. 1981. Variation in phenotypic mixing among pepper-infecting potyviruses. Phytopathology 71: 245.

Ramírez- Martínez, C. \& R. Gámez. 1980. Prevalencia del virus $\mathrm{X}$ en plantaciones comerciales de papa en la zona del Volcán Irazú, Cartago, Costa Rica. Agron. Costarricense 4: 79-82.
Salazar, L.F. 1995. Los Virus de la Papa y su Control. Centro Internacional de la Papa, Lima, Perú. 226 p.

Savenkov, E., M. Sandgren \& P. Valkonen. 1999. Complete sequence of RNA 1 and the presence of tRNA-like structures in all RNAs of Potato mop-top virus, genus Pomovirus. J. Gen. Virol. 80: 2779-2784.

Solís, V.C. 1989. Indice de enfermedades de los cultivos agrícolas de Costa Rica. Ministerio de Agricultura y Ganadería-Dirección de Sanidad Vegetal. Convenio Costarricense Alemán de Sanidad Vegetal MAGGTZ, San José, Costa Rica. 112 p.

Spetz, C., A.M. Taboada, S. Darwich, J. Ramsell, L.F. Salazar \& J.P.T. Valkonen. 2003. Molecular resolution of a complex of potyviruses infecting solanaceous crops at the centre of origin in Peru. J. Gen. Virol. 84: 2565-2578.

Stevenson, W. 2001. Compendium of potato diseases. American Phytopathological Society. St. Paul, Minnesota, EEUU. p. 57-72. 
